\title{
New Ways of Working and the Physical Environment to Improve Employee Engagement
}

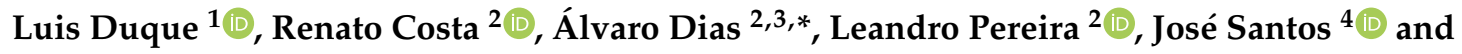 \\ Nelson António 2 \\ 1 FGV, Rodovia Raposo Tavares, 3412-Jardim Pinheiros, Sao Paulo, Brazil; luiz.duque@fgv.br \\ 2 ISCTE-IUL, Avenida das Forças Armadas, 1649-026 Lisbon, Portugal; renato_jorge_costa@iscte-iul.pt (R.C.); \\ leandro.pereira@iscte-iul.pt (L.P.); nelson.antonio@iscte-iul.pt (N.A.) \\ 3 Universidade Lusófona, Campo Grande 376, 1749-024 Lisbon, Portugal \\ 4 WINNING Lab, Alameda das Linhas de Torres, 152 Escritório, 141750-149 Lisbon, Portugal; \\ jose.santos@winning.pt \\ * Correspondence: alvaro.dias@ulusofona.pt; Tel.: +35-19-1474-0112
}

Received: 9 June 2020; Accepted: 14 August 2020; Published: 20 August 2020

check for updates

\begin{abstract}
Employee engagement is becoming an increasingly essential factor in organizational competitiveness. Although employee engagement is an extensively researched topic, the roles of new ways of working and physical environment factors are still under exploited. As such, this study examines the relationship between physical environment factors, the dimensions that integrate new ways of working, and employee engagement. Survey data with 126 respondents are analyzed using structural equation modeling. The findings indicate a positive significant relationship between the physical environment factors and work engagement. Furthermore, this relation is mediated by four facets regarding new ways of working. The results also indicate that, for the group where facilities were not modified, the new ways of working are a stronger predictor of work engagement when compared with the group where facilities were modified. These findings extend existing knowledge on the antecedents of employee engagement, namely physical environment factors and new ways of working. Another important contribution is related to the mediating role of several facets of new ways of working in the relationship between physical environmental factors and employee engagement.
\end{abstract}

Keywords: new ways of working; performance; structural equation modeling; work engagement

\section{Introduction}

In a rapidly changing society, where growth in information volume has generated profound social changes, the discussion about the future of the physical work environment gains important contours $[1,2]$. In parallel to these changes, there is a growing need to improve working conditions so that the reduction of the management structure can maintain or even exceed its performance $[1,3]$. This concern has given rise to what the scientific literature indicates as New Ways of Working (NWW) [4-7]. An increasing number of organizations have been looking to implement NWWs in search of a readjustment of their management practices to stay competitive in the market, reduce operating costs and increase productivity [8].

NWW encompasses five facets, which are: (i) management of output, (ii) access to organizational knowledge, (iii) flexibility in working relations, (iv) a freely accessible open workplace and (v) timeand location-independent work [1-3,6,9].

However, to encourage the adoption of NWW, organizations must also adjust their physical facilities where employees perform their activities $[4,10,11]$. As such, there is an increasing process of transformation in traditional environments of work. The spaces designed for individual employees 
have been changing in favor of large collective spaces [10,12]. At the same time, technology assumes roles that were previously performed exclusively by individuals streamlining process execution and becoming obsolete various organizational functions [13].

In the context of the drastic changes that the world is passing through due to the COVID-19 pandemic, the relationship between the work environment's physical aspects and the NWW is even more relevant. Around the world, organizations' higher management is adapting all their structure to this new paradigm. At the same time, NWW's facets as access to organizational knowledge, flexibility in working relations, and time- and location-independent work are being heavily used in this new perspective. Even though these research findings could not be generalized, we believe that due to the exceptionality of this moment, our research may contribute to understanding the interrelationship of these two essential factors for the work environment in the XXI century. The theme of employee engagement has been an object of extensive investigation (c.f. [14]). However, the analysis of the NWW as an antecedent of employee engagement needs further research [15]. Previous research investigated only direct effects [16] or specific indirect effects considering social interaction and transformational leadership as mediators [3]. However, the direct and indirect effect of physical environment factors on employee engagement and the effect of NWW on employee engagement are still under explored. As such, the objectives of this research are (i) to investigate the relationships between physical environmental factors and NWW and employee engagement, and (ii) to assess the relationship between NWW and employee engagement.

Based on survey data analyzed using structural equation modeling, this study presents three main contributions. First, by identifying the essential role of Physical Environment Factors (PEF) in employee engagement, recognizing the direct and indirect influence through the mediating role of several facets of NWW. Secondly, the direct influence of NWW on employee engagement is also recognized. Third, the study also identifies the direct influence of PEF on the NWW, extending the existing knowledge on the antecedents of employee engagement.

This article is structured as follows. Section 2 presents the literature review and the research hypothesis. Section 4 details the methodology. The next section presents the analysis procedures, and the results are described in Section 5. Section 6 discusses the results, presents the conclusions, implications and limitations, and future research suggestions.

\section{Literature Review}

\subsection{The New Ways of Working (NWW)}

The New Ways of Working (NWW) come from the areas of human resources administration and management [4]. During the period when the subject still lacked more concrete definitions, many scholars referenced it interchangeably by terms such as telework, flexible work, and mobile work [17].

As far as IT evolved, the so-called "virtual world" and digital tools have reduced the need for synchronous communication and mobilization office employees to perform tasks $[6,10]$. At that time, it has become clear that the New Ways of Working involved aspects that went beyond the limits of technology $[8,18]$ and the work environment and relationships between employees began to get more attention.

Several studies seek to reflect on NWW [19,20]. According to De Leede and Kraijenbrink [21], there are three main aspects: flexibility, work at home and work together at a distance.

Slagter [22] argues that NWWs consists of four facets, namely: time- and location-independent work; independent production management; access to organizational knowledge and flexibility in work relationships. Although Slagter's [22] classification is the most widely used, it does not address aspects related to the physical and mental interaction between work environments, which, even at a distance, is an indispensable facet of the definition of the NWW [23]. The first three facets have related to aspects that encourage the so-called teleworking. The fourth and fifth facets have related to aspects that are internal to the physical work environment. Regarding the fourth facet of NWW-Flexibility in 
working relationships-both Branine [24] and Kossek and Lee [25] reflect that employees who share workplaces cite as advantages of this provision the transfer of experience, as well as the mutual support and help they receive from each other with their colleagues.

Regarding the fifth facet of NWW, a freely accessible workplace, it has a purpose to minimize the physical and mental distance in the workplace, stimulating meetings, and cooperation between colleagues. Table 1 contains the five facets of NWW, their respective concepts, and references.

Table 1. Facets of New Ways of Working (NWW) and their definitions.

\begin{tabular}{ccc}
\hline NWW Facets & Definition & Authors \\
\hline Time- and location-independent of work & $\begin{array}{c}\text { Performing work outside the organization's } \\
\text { physical environment and at alternate times }\end{array}$ & {$[7,22]$} \\
\hline Independent production management & $\begin{array}{c}\text { The employee has more flexibility to define } \\
\text { the way and the pace of delivery of } \\
\text { their demands. }\end{array}$ & {$[3,4,22]$} \\
Access to organizational knowledge & $\begin{array}{c}\text { Employees have greater access to information } \\
\text { needed to perform their duties and the ability } \\
\text { to interact with colleagues and managers. }\end{array}$ & {$[2,26,27]$} \\
\hline Flexibility in labor relations & $\begin{array}{c}\text { Employee freedom to adjust work functions } \\
\text { to those of their personal life }\end{array}$ & {$[7,8]$} \\
\hline Local of freely accessible work & $\begin{array}{c}\text { Permission for employees to attend } \\
\text { workplaces and perform their duties at } \\
\text { various times }\end{array}$ & {$[12,28]$} \\
\hline
\end{tabular}

Source: prepared by the authors (2019).

The following section presents the relationship between employee engagement and work performance with new ways of working.

\subsection{The Relationship between Employee Engagement and Performance at Work in the Context of New Ways} of Working

The relationship between employee engagement and work performance is widely studied in the literature $[29,30]$. However, most of the empirical evidence that presents performance indicators in the study of this relationship is still incipient [31]. As stated by Demerouti et al. [31], the literature on work engagement is based on pre-existing constructs. In this context, are inserted the facets of New Ways of Working, like practices to reduce stress, and at the same time promote work engagement. Ultimately, the adoption of NWW facets acts on two fronts, promoting increased work performance [27,31,32].

The studies about NWW must contemplate the interrelationship between facets and the physical environment $[6,10,12]$. Therefore, the following section presents the Physical Environment Factors (PEF) to be analyzed in this investigation.

\subsection{The Influence of Physical Environment Factors on Work Performance}

The importance of the quality of the physical environment can be measured by its most direct consequences for organizations. Becker and Sims [33] sought to measure the cost of so-called turnover (variation between input and output of employees), which usually has a direct link to poor physical working environments, concluding that a reduction from $30 \%$ to $15 \%$ would represent savings of USD 60,000 per employee in the USA. Similarly, Duffy and Powell [34], measuring the reduction turnover of a financial services firm in Australia, observed a reduction of $11 \%$ after refurbishment was carried out in its physical facilities. Table 2 presents the physical environment factors that influence employees in the workplace, their implications, and references. 
Table 2. Physical environment factors and their implications for employees.

\begin{tabular}{ccc}
\hline Physical Environment Factors & Implications & Authors \\
\hline Air quality & $\begin{array}{c}\text { Increased work engagement. Reduction of } \\
\text { downtime and absenteeism }\end{array}$ & {$[9,35]$} \\
Temperature & $\begin{array}{c}\text { Maintaining adequate levels reflects } \\
\text { positively on individual aspects of work } \\
\text { such as self-esteem, confidence, } \\
\text { engagement, and employee satisfaction. }\end{array}$ & {$[36]$} \\
Ergonomics & $\begin{array}{c}\text { Reduces occupational injuries resulting } \\
\text { from repetitive stress. Contributes to } \\
\text { increased productivity. }\end{array}$ & {$[37,38]$} \\
\hline Physical environment factors & Implications & Authors \\
\hline Ambient lighting & $\begin{array}{c}\text { Adequate levels of ambient lighting help } \\
\text { increase productivity, reduce employee } \\
\text { absenteeism and well-being. }\end{array}$ & {$[35]$} \\
\hline Noise Levels & $\begin{array}{c}\text { Moderate noise levels promote comfort and } \\
\text { well-being and work engagement }\end{array}$ & {$[35,39,40]$} \\
\hline
\end{tabular}

The physical environment factors presented can be directly influenced by the density in the workspace, affecting the comfort and the health quality in the environment [41,42]. Therefore, a constant senior management assessment is required for workspace readjustment [39]. The following section presents the hypotheses to be tested and the model proposed in this investigation.

\subsection{Hypothesis Development and Conceptual Model}

In the study by Ten Brummelhuis et al. [43], the authors found that the implementation of the facets of new ways of working is positively related to employee engagement. At the same time in the study by Van Steenbergen et al. [11], the authors concluded that reducing the workload and the task ambiguity and increasing autonomy of employees were related positively to reducing burnout and fostered work engagement.

Gerards et al. [3], in a study about the facets of new ways of working, concluded that three of them are positively related to employee engagement. They are (i) access to organizational knowledge, (ii) free access to the work environment, and (iii) independent production management. According to Vischer and Wifi [44], the constant monitoring of workers' perceptions of their working conditions is an essential tool for continuously improving their working environment. In this regard, it is necessary to periodically evaluate the physical work environment to adapt it to technological and organizational evolution [45]. Among the facets of the new ways of working, (i) time- and location-independent work, (ii) flexibility in working relationships and (iii) a freely accessible workplace, require not only changes in the management of organizations but also in the adequacy from physical installations to this new reality $[10,28,46,47]$.

However, success in designing virtual environments to promote flexibility in time and workspace, or even implementing physical environments that adapt to more flexible forms of working relationships, depends on top management support to achieve alignment with the strategy and culture of the organization [27].

Furthermore, Ten Brummelhuis et al. [43] found NWW to play a crucial role in work engagement, with the mediate role of social interaction. In the same vein, Gerards et al. [3] also highlighted the relationship between one or more individual facets of NWW and employee behavior. As such, according to the literature review, we realize that physical working conditions play an essential role in employee satisfaction and especially in employee engagement. It was found that this factor is 
also strongly linked to NWW, suggesting not only a direct relationship as a mediator in employee engagement. Therefore, we consider the following hypotheses:

Hypothesis 1 (H1): Physical work factors have a positive relationship with employee engagement.

Hypothesis 2 (H2): Physical work factors environment has a positive relationship with new ways of working.

Hypothesis 3 (H3): New Ways of Working has a positive relationship with Employee Engagement.

Hypothesis 4 (H4): The relationship between the facets of new ways of working and employee engagement is mediated by the perception of physical environment factors.

Hypothesis 5 (H5): The relationship between the facets of the new ways of working and employee engagement is moderated by physical environment factors.

Figure 1 shows the research model, the structural relationships between the constructs and the hypotheses to be tested.

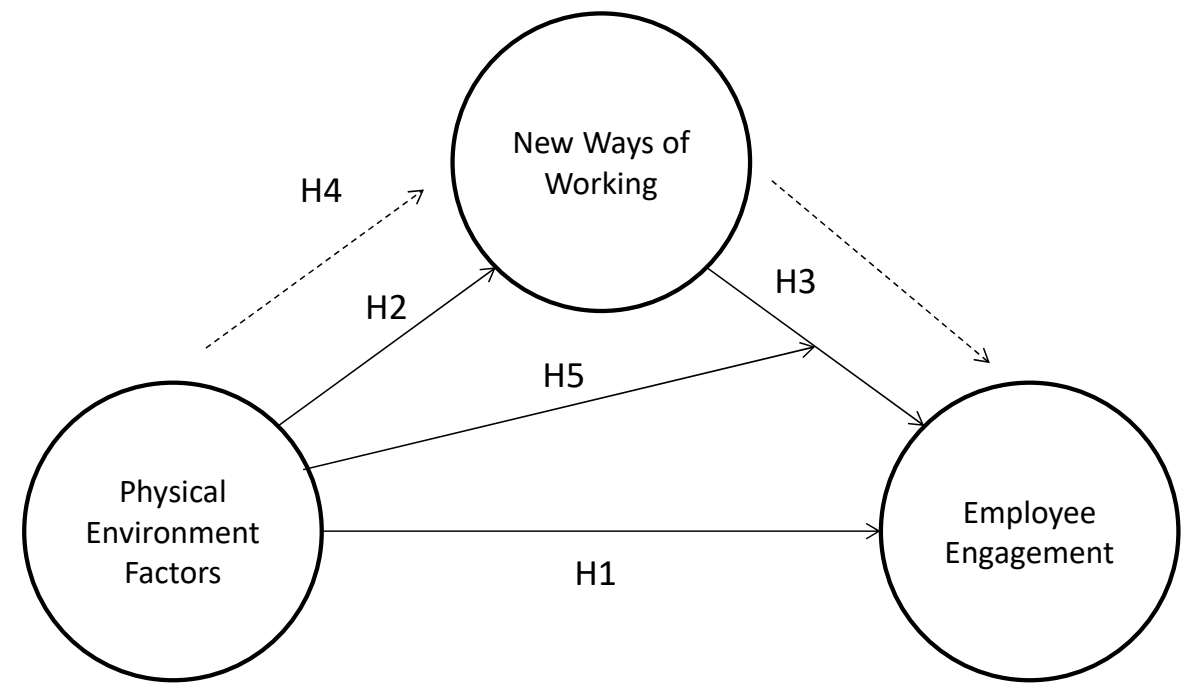

Figure 1. Conceptual Model. Source: the authors. Note: the intermittent line represents the mediate relation.

The next chapter presents the methodological path that was followed for the execution of the research.

\section{Methodology}

This research uses a case study research design for examining the identified problem. As suggested by Seawright and Gerring [48], case selection incorporates not only practical considerations such as time and access to information but also provides an opportunity to pursue action leading to the reach research objectives. The following protocol was followed to identify the most appropriate case. First, a list of the world's leading companies was identified regarding their role in policymaking for government and civil society. As such, a shortlist of relevant institutes was taken from 2018 Global Go To Think Tank Index Report [49], a ranking that identifies leading policy institutes for governments and civil societies around the world. The top 10 institutes are presented in Table 3. 
Table 3. Top think tanks worldwide.

\begin{tabular}{l}
\hline 1. Brookings Institution (United States) \\
\hline 2. French Institute of International Relations (IFRI) (France) \\
\hline 3. Carnegie Endowment for International Peace (United States) \\
\hline 4. Bruegel (Belgium) \\
\hline 5. Center for Strategic and International Studies (United States) \\
\hline 6. Fundação Getúlio Vargas (FGV) (Brazil) \\
\hline 7. Chatham House (United Kingdom) \\
\hline 8. Heritage Foundation (United States) \\
\hline 9. RAND Corporation (United States) \\
\hline 10. International Institute for Strategic Studies (IISS) (United Kingdom) \\
\hline \multicolumn{1}{c}{ Source: McGann [49]. }
\end{tabular}

Second, the entities were selected in a score from 1 to 10 according to two criteria: (i) performance in varied areas of activity; (ii) occurrence of relevant changes in the physical environment; and (iii) availability and willingness to facilitate access to relevant information. Based on these criteria, the top candidate was Fundação Getúlio Vargas (FGV). The selected case study is considered as adequate to extend the relevant research in this field by exploring the relationships between physical environmental factors and NWW and employee engagement, as well as the relationship between NWW and employee engagement.

FGV was created on December 20, 1944, in Rio de Janeiro as a nonprofit entity to provide services to society. The initial purpose was to qualify professionals for public and private administration. The institution has a strong tradition in cutting-edge higher education and has helped to educate key decision makers over the years in Brazil and around the world [50]. This organization was chosen to carry out this study because it is an international reference and pioneer in the adoption of new management and work practices, revealing to be an ideal field of investigation for the subject of this study.

FGV is a Brazilian center of excellence for quality education, research, and projects. For almost 70 years, the institution is one of the leaders of the country's social and intellectual development. In numbers of 2019, FGV encompassed over 90 centers for studies and research.

According to a recent report of the University of Pennsylvania, FGV was ranked in the 5th position of the Global Top Think Tanks Index-the 1st in Latin America and the Caribbean [49]. As can be perceived by the diversity of knowledge branches, in FGV's units and staff, there is an intense interaction between scholars and practitioners. In Brazil, FGV is one of the first institutions to promote the integration of these two "separate" worlds. The collaboration between practice and scholars stimulates the use of the most recent knowledge in several areas.

For example, following recent academic studies, in the last five years, FGV's higher management has been working to improve all the units' physical installations. In parallel, FGV was one of the pioneers in Brazil to stimulate among its workers, the implementation of the termed New Ways of Working (NWW). In the year of 2019, two of the leading FGV units (in Rio de Janeiro and São Paulo) initiated the physical reformulations to improve the following aspects: (i) air quality, (ii) temperature, (iii) ergonomics, (iv) ambient illumination and (v) noise levels. According to Yin [51], a researcher may conduct a single case when there is a rare or unique circumstance to be observed. We collected the data in these two FGV units during the period in which these improvements were being carried out. Therefore, we could assess how the two groups (NMod-the group in which the facilities have not been modified; Mod-the group in which the facilities were modified) perceived the relationship of the new ways of working facets and the physical environment.

The research was carried out in a cross-sectional analysis, having as its unit of analysis the employees of Fundação Getúlio Vargas (FGV). Data from 125 respondents were collected between 
June and August 2019 through a link sent to employees. This period was considered to be the time when fewer workers are on vacation, to maximize the quantity and representativeness of the sample. The questionnaire was made available on the Qualtrics platform [52]. The research sample was defined by convenience and is therefore not probabilistic. It is justified by the fact that the focus of the research is limited to the employees of FGV. The inclusion criteria were to be an employee of FGV and to have work contracts with the institution. The exclusion criterion was not having a work contract; as such, all service providers were excluded from the survey.

The quantitative research began with the development of the data collection instrument. For this, a search in the indexers was performed: Web of Science, Google Scholar, Scopus, and Scielo. The following English terms were used to search the titles of scientific articles and books: "New Ways of Working" and "Performance". The same terms were also searched for in their Portuguese translation.

The survey questionnaire was constructed to include the following variables presented in the work of Gerards et al. [3]: "New Ways of Working" and "Employee Engagement". The third variable, "Physical Environment Factors" was drawn from the literature referenced in this research.

The air quality and temperature factors were measured together, because of its nature and similarity $[9,35]$. The items comprising the first two constructs instrument (New Ways of Working and Employee Engagement) were translated from the questionnaire by Gerards et al. [3] to Portuguese and adapted according to the socio-cultural characteristics of the respondents. As a way to investigate the relations proposed in the objective, the facets of the new ways of working were homogeneously analyzed. Similarly, the factors of the physical environment were also gathered in one construct.

The first section of the questionnaire aimed to identify the socio-demographic characteristics of respondents: (i) age, (ii) profession, (iii) gender, (iv) educational level, (v) organizational role, and (vi) working time in the organization. Additionally, two closed questions were presented to ascertain whether the employee was aware that the organization's facilities were recently modified or upgraded and whether they worked in the organization before this change. The statements of the questionnaire were presented on a scale like Likert of seven points. To increase the face validity of the instrument, the questionnaire was submitted to the analysis of two masters and a doctoral student from the area of the administration who made suggestions for changes. The research proposed in this research was based on primary sources.

After data tabulation, incomplete responses were discarded. The second step was to verify the responses characterized as outliers. For this, the following criterion was adopted: the frequency of responses of each individual for the seven points of the scale was measured. If the answers had a concentration percentage higher than $60 \%$ in only one point of the scale, the questionnaire was discarded from the analysis.

\section{Analysis}

Data collection involved employees working in the administrative, academic, managerial, and strategic sectors in the cities of Rio de Janeiro and São Paulo. After debugging and compiling the database, a total of 86 valid responses were obtained. The average age of respondents was 38 years. Of the total, $46.5 \%$ are male and $53.5 \%$ female. Regarding the level of education, the majority $(64.70 \%)$ of respondents are postgraduates, then totaled $25.88 \%$ who have a degree. In Table 4 , the data are presented in more detail.

Regarding the age of respondents, most are in the range between 30 and 35 years (21 individuals). FGV operates in various areas, from consulting to educational services. This segmentation is perceived by analyzing the position of respondents in the survey. Most of them, 26 individuals, were working in administrative positions. Next, consultants (13), coordinators (11), and managers (11). Academics and technicians totaling eight individuals in each category. In the last positions were strategic positions (five) and analysts (four).

Regarding working time, the majority $(37,2 \%)$ of employees are in the organization between 1 and 5 years. Then, $25.6 \%$ of respondents are individuals who are between 5 and 10 years in the organization. In a smaller percentage, $18.6 \%$ of employees had worked in the organization for between 
10 and 15 years. The extreme points (less than one year and more than 15 years) presented the lowest percentages, with $9.3 \%$ in each group. The data were analyzed using SPSS statistical analysis software (version 23) and SmartPLS (version 3.2.8). Additionally, Excel was used to tabulate the database.

Table 4. Respondents' sociodemographic profile.

\begin{tabular}{cccc}
\hline Demographic Profile and Use Characteristics of Smartphones & Number & Percentage (\%) \\
\hline Genre & Male & 40 & 46.5 \\
& Feminine & 46 & 53.5 \\
& $20-25$ & 7 th & 8.2 \\
Age years & $25-30$ & 13 & 15.1 \\
& $30-35$ & 21 & 24.4 \\
& $35-40$ & 13 & 15.1 \\
& $40-45$ & 11 & 12.8 \\
& $45-50$ & 9 & 10.5 \\
& $50-55$ & 3 & 3.5 \\
& $55-60$ & 4 & 4.6 \\
Degree of Instruction & $60-65$ & 3 & 3.5 \\
& $>65$ & 2 & 2.3 \\
& Second degree completed & 5 th & 5.8 \\
& University graduate & 22 & 25.88 \\
Working time in the organization & Specialization & 4 & 4.7 \\
& Postgraduate studies & 55 & 64.7 \\
Renovated/modified facilities & Less than 1 year to 5 years & 8,32 & $9.3,37.2$ \\
Present before & to 10 years to 15 years & 22,16 & $25.6,18.6$ \\
renovations/modifications & More than 15 years & 8 & 9.3 \\
& Yes & 39 & 45.9 \\
& Not & 47 & 54.1 \\
& Yes & 38 & 44.7 \\
\hline
\end{tabular}

The validation of the instrument began in the pretest phase in which 33 answers were obtained from employees of the institution. Items that presented corrected item-total correlation indices below 0.300 were removed, following the recommendations of Pedhazur and Schmelkin [53]. In the final version of the questionnaire, nine of the 38 items did not present the recommended indexes so that it was possible to proceed with the instrument validity and reliability tests $[54,55]$ and, therefore, were withdrawn.

The KMO test resulted in an index of 0.837 . Coefficients above 0.6 indicate the appropriateness of the sample for factor analysis [56]. The presence of correlation between the items was analyzed by Bartlett's sphericity test. The test was significant at a confidence level of $99 \%$ and an index of 1,813,873 was obtained. After debugging the instrument, a new collection was performed. The final number of valid answers was 86 questionnaires, so above the minimum number of 68 respondents.

Minimum sample estimation was performed using GPower software [57] using the parameters recommended by Cohen (1992) for the multiple linear regression method. Due to the predictive and exploratory character of the research, PLS-SEM was adopted as a statistical technique to test the hypotheses proposed in the model. For the implementation of technical statistics, the recommendations of Hair et al. have been implemented [58].

Additionally, the sample normality test indicated that the data are not normalized. This second finding reiterates the choice made by the data analysis method, whereas the literature largely recommends the choice of the PLS-SEM statistical technique over the covariance analysis (CB-SEM) technique when data are not normally distributed [59].

\section{Results}

\subsection{Measurement Model Analysis}

After debugging the database and validating the instrument, the measurement model was analyzed. Considering that the model under analysis is composed of reflective items, the evaluation of the measurement model involves the respective reliability criteria: (i) item reliability, (ii) construct reliability, and (iii) internal consistency. The statistical indices used to evaluate the three criteria were: 
the corrected item-total correlation (CITC), the latent and cross loads, the Cronbach's alpha (CA), Composite Reliability (CR), and the Average Variance Extracted (AVE). All items had CITC indices above the recommended parameter of 0.5 (Hair et al., 2017). The respective Cronbach's alphas also had indices above 0.7 , indicating the internal consistency of the constructs.

According to Henseler et al. [60], the reliability of each reflective item is measured by its latent load about its respective construct. The authors recommend that the rates be at least 0.7 . Although eight of the 29 indicators in the final questionnaire had external loads below the 0.7 index (yet all above 0.6), the results of the Average Variance Extracted (AVE) show that they contribute to the measurement of their respective constructs [60]. Therefore, they were kept in the model evaluation.

The second procedure consisted of verifying the convergent validity, estimated through the AVE. The three constructs presented indices higher than 0.50, which concludes that at least half of the variance of each construct can be attributed to the items that compose them $[61,62]$. Before proceeding with the discriminant validity test, the item significance test, and the internal consistency of the constructs are presented. In Table 5, latent loads of items, the composite reliability (CC), Cronbach's alpha (AC), and the average variance of the extracted constructs (AVE) are exposed.

Table 5. Latent loads, Cronbach's alpha, average variance extracted, and composite reliability of items and constructs.

\begin{tabular}{|c|c|c|c|c|c|}
\hline Construct/Dimension/Item & Latent Loads & $t^{*}$ Values & $\mathrm{AC}^{\mathrm{a}}$ & $C C^{b}$ & $\mathrm{VME}^{\mathrm{C}}$ \\
\hline Work Engagement & & & 0.930 & 0.943 & 0.676 \\
\hline Work Engagement 2 (ET2) & 0.886 & 37.957 & & & \\
\hline Work Engagement 3 (ET3) & 0.878 & 31.898 & & & \\
\hline Work Engagement 4 (ET4) & 0.889 & 26.595 & & & \\
\hline Work Engagement 5 (ET5) & 0.867 & 25.396 & & & \\
\hline Work Engagement 6 (ET6) & 0.745 & 12.810 & & & \\
\hline Work Engagement 7 (ET7) & 0.764 & 13.455 & & & \\
\hline Work Engagement 8 (ET8) & 0.652 & 6.055 & & & \\
\hline Work Engagement 10 (ET10) & 0.864 & 25.761 & & & \\
\hline Physical Environment Factors & & & 0.924 & 0.934 & 0.504 \\
\hline Sound Comfort 1 (ConfSon1) & 0.779 & 13.603 & & & \\
\hline Sound Comfort 1 (ConfSon2) & 0.794 & 12.740 & & & \\
\hline Ergonomics 1 (Erg1) & 0.780 & 15.415 & & & \\
\hline Ergonomics 2 (Erg2) & 0.810 & 16.893 & & & \\
\hline Ergonomics 3 (Erg3) & 0.654 & 10.034 & & & \\
\hline Layout1 (Lay1) & 0.753 & 12.765 & & & \\
\hline Layout2 (Lay2) & 0.705 & 10.128 & & & \\
\hline Layout4 (Lay4) & 0.797 & 15.129 & & & \\
\hline Privacy 1 (Priv1) & 0.678 & 8.437 & & & \\
\hline Privacy 2 (Priv2) & 0.655 & 7.001 & & & \\
\hline Privacy 3 (Priv3) & 0.608 & 7.325 & & & \\
\hline Temperature and Air Quality 1 (Temp1) & 0.626 & 8.427 & & & \\
\hline Temperature and Air Quality 2 (Temp2) & 0.728 & 15.071 & & & \\
\hline Temperature and Air Quality 2 (Temp3) & 0.733 & 13.950 & & & \\
\hline New ways of working & & & 0.855 & 0.889 & 0.534 \\
\hline Access to Organizational Knowledge 1 (CI1) & 0.690 & 9.942 & & & \\
\hline Access to Organizational Knowledge 2 (CI2) & 0.677 & 9.288 & & & \\
\hline Time and Space Flexibility 2 (FL2) & 0.669 & 8.852 & & & \\
\hline Time and Space Flexibility 3 (FL3) & 0.740 & 12.478 & & & \\
\hline Independent Production Management 1 (GS1) & 0.811 & 16.647 & & & \\
\hline Independent Production Management 2 (GS2) & 0.774 & 13.095 & & & \\
\hline Flexibility in Labor Relations (SPP1) & 0.742 & 12.285 & & & \\
\hline
\end{tabular}

The discriminant validity (the extent to which items in a given construct differ from items in other constructs) was assessed by two criteria. First, according to the Fornell-Larcker criterion [63], the square root of the AVE indices of each of the constructs must be greater than their correlation with the 
others. The three investigated constructs met this condition. Table 6 shows the discriminant validity by the Fornell-Larcker criterion, the average and standard deviation of the constructs.

Table 6. Discriminant validity by the Fornell-Larcker criterion.

\begin{tabular}{cccc}
\hline Construct & Work Engagement & Physical Environment Factors & NWW \\
\hline Work Engagement & 0.822 & & \\
Physical Environment Factors & 0.463 & 0.710 & 0.731 \\
NWW & 0.591 & 0.492 & 4.70 \\
Average & 5.478 & 4.38 & 1.954 \\
\hline Standard deviation & 1.360 & 1.766 & \\
\hline
\end{tabular}

The second criterion used to assess discriminant validity was the straight-trait mono track correlation ratio [64]. The indices presented values below 0.85 , as recommended by the literature [64].

\subsection{Structural Model Analysis}

After analysis of the measurement model, the structural model was examined. This stage of the analysis is to identify the strength, significance, the total variance explained by the endogenous constructs and predictive relevance of the model $[59,64]$. The multicollinearity analysis was performed by observing the Variance Inflation Factor (VIF). According to Hair et al. (2017), values between 0.2 and 5 indicate that there is no negative influence of multicollinearity between items. The values of the independent variables so as dependent varied between 1.6 and 3.9.

The predictive relevance of the model was calculated by the Stone-Geisser index $\left(\mathrm{Q}^{2}\right)$. The blindfolding test was performed, with the omission distance of seven points, according to the recommendations of Hair et al. [58]. Cross-validation of endogenous constructs showed values above zero, EIN (0.240), and NWW (0.105). The results confirm the predictive relevance of the model. Additionally, the indicators were subjected to the Harman factor test [65]. In this procedure, all constructs are analyzed by the principal component analysis method, and, if the indicators extracted in a single factor have an explained variance percentage greater than $50 \%$, this variance can be attributed to the method used by the measurement and not by the constructs to be measured [61,66]. In the final instrument, the explained variance percentage reached $33.7 \%$.

The PLS algorithm analysis demonstrated that $37.6 \%$ of the variance of the endogenous latent construct in work engagement (EIN) can be explained by the physical factors of the environment (PFE) and the NWW. Another result observed in the analysis was that $23 \%$ of the variance of the endogenous construct can be explained by NWW physical environmental factors. Figure 2 presents the model, its structural relationships, latent loads, path coefficients (beta), and the variance explained by endogenous constructs.

The next step in the structural model evaluation was to verify the significance of the results obtained from the standardized path coefficients (betas) of the model. The bootstrapping resampling technique with 5000 samples was performed following the recommendations of Hair et al. [62]. This statistical technique aims to assess the significance of the indices found in the measurement and structural model evaluation.

At a significance level of $95 \%(p<0.05)$, the validity of the standardized path coefficients $(\beta)$ was tested. Table 7 presents the hypotheses, the indices, and the decision about their validity.

At a significance level of 95\%, Hypotheses 1, 2, 3 and 4 were confirmed. The results indicate the influence of PEF on both work engagement and NWW facets. These in turn also directly and positively influence work engagement. Hypothesis 5 was not confirmed, indicating that PEFs do not act as moderators of the relationship between NWW and work engagement.

This information provides us with evidence to support research by researchers who argue that changes in the physical work environment alone or the implementation of facets of the NWW alone are not enough to promote work engagement and employee performance $[3,6]$. This finding is one of the 
topics discussed in the concluding chapter of this document. Hypothesis 4, which was investigating the mediation of the facets of the NWW in the relationship between environmental physical factors and work engagement, was confirmed. The mediation analysis is presented and discussed in the following section.

Table 7. Test of hypothesis relation between constructs.

\begin{tabular}{|c|c|c|c|c|c|c|}
\hline Hypotheses & Ways & $\begin{array}{l}\text { Path Coefficient } \\
(\beta)\end{array}$ & $\begin{array}{l}\text { Standard } \\
\text { Error }\end{array}$ & Est. $t^{\mathrm{a}}$ & $p *$ Value & Decision \\
\hline H1 & $\mathrm{PEF} \rightarrow$ Work Eng. & 0.223 & 0.117 & 2.001 & 0.049 & Supported \\
\hline $\mathrm{H} 2$ & $\mathrm{PEF} \rightarrow \mathrm{NWW}$ & 0.489 & 0.070 & 7.231 & 0.000 & Supported \\
\hline $\mathrm{H} 3$ & $\mathrm{NWW} \rightarrow$ EIN. & 0.485 & 0.117 & 4.215 & 0.000 & Supported \\
\hline $\mathrm{H} 4$ & $\mathrm{PEF} \rightarrow \mathrm{NWW} \rightarrow \mathrm{EIN}$ & $0.460^{* *}$ & - & - & - & Supported \\
\hline H5 & $\mathrm{PEF} \rightarrow(\mathrm{NWW} \rightarrow \mathrm{EIN})$ & 0.143 & 0.111 & 1.290 & 0.197 & Not Supported \\
\hline
\end{tabular}

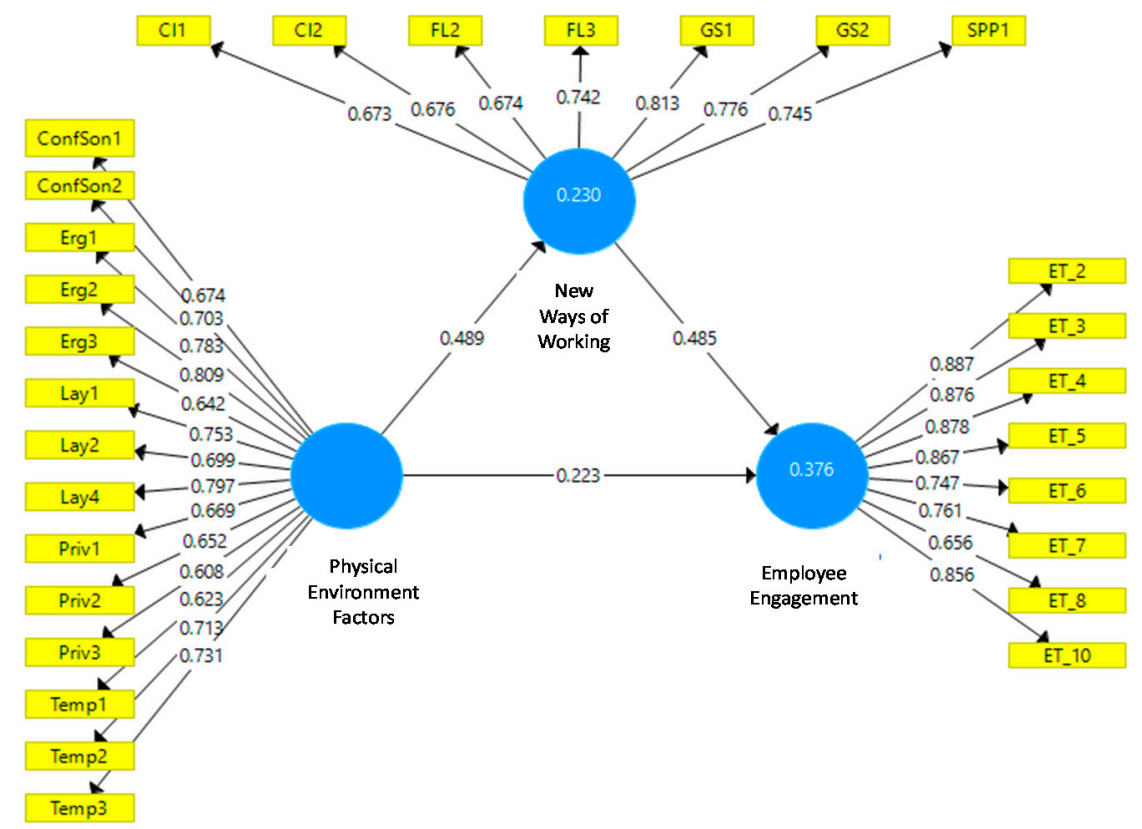

Figure 2. Model results.

\subsection{Mediation Analysis}

The analysis of the mediating effect of physical environmental factors on the relationship between the facets of new ways of working and work engagement was carried out following two recommendations. The first, by Hair et al. [58], consists of observing the total effect of the independent variable (in this case, physical environment factors), on the dependent variable (work engagement). The total effect corresponds to the sum of the direct and indirect effects. Table 8 shows the indices.

Table 8. Direct, indirect and total effects.

\begin{tabular}{cccc}
\hline Relationship & Direct Effect & Indirect Effect & Total Effect \\
\hline $\mathrm{PEF} \rightarrow \mathrm{NWW} \rightarrow \mathrm{EIN}$. & 0.223 & 0.237 & 0.460 \\
\hline
\end{tabular}

Note: PEF-Physical Environment Factors; NWW—New Ways of Working; EIN-Work Engagement.

Baron and Kenny's [67] second recommendation consists in observing four assumptions: (i) the independent variable should significantly affect the relationship with the mediating variable so that it is not null, (ii) the independent variable should significantly affect the dependent variable when removing the mediating variable, (iii) the mediating variable has a significant effect on the dependent 
variable and (iv) by adding the mediating variable to the model, the effect of the independent variable on the dependent variable should become weaker.

Table 7 presents the results from the direct relationships of the structural model. The results indicate that $37.6 \%$ of the variance in the construct "Employee Engagement" can be explained by the proposed model. A value of less than $50 \%$ indicates that the relationship between physical environmental factors and NWW facets has a power that lies between the "small" and "moderate" rates of employee variance explanation [68]. By withdrawing the variable mediator (NWW), the strength of the path increases $(\beta=0.476)$. This finding obeys one of the assumptions fundamental to Baron and Kenny [67] to certify the occurrence of mediation.

From the results of the analysis, it is possible to verify that the facets of the new ways of working, jointly, act partially as a mediator of the relationship between the factors of the physical environment and employee engagement. Considering that the existence of mediation depends on the significance of the relationship between the independent variable and the mediator or between the mediator and the dependent variable [69], Table 9 shows the path coefficients, the standard deviations, the $t$ values, and the $p$ values relations.

Table 9. Pathway Significance Test.

\begin{tabular}{ccccc}
\hline Ways & $\boldsymbol{\beta}$ & Standard Deviation & Est. $\boldsymbol{t}^{\text {a }}$ & $\boldsymbol{p}$ Values * \\
\hline $\mathrm{PEF} \rightarrow \mathrm{EIN}$ & 0.223 & 0.117 & 2.001 & 0.049 \\
$\mathrm{PEF} \rightarrow \mathrm{NWW}$ & 0.489 & 0.068 & 7.231 & 0.000 \\
$\mathrm{NWW} \rightarrow$ EIN & 0.485 & 0.115 & 4.215 & 0.000 \\
\hline
\end{tabular}

Note: ${ }^{a} t$-value for a two-tailed test: ${ }^{*} 1.96$ (significance level: $95 \%$ ); PEF-Physical Environment Factors; NWW-New Ways of Working; EIN-Work Engagement.

In the following section, we present the analysis of the search model parameters between the groups in which the facilities were modified and what the facilities did not undergo modifications.

\subsection{Analysis between Groups}

The analysis of the proposed model considered the four categorical variables (gender, education, working time in the organization, and modifications in the facilities). The four control variables were tested to see if they influenced work engagement. Only the variable "Facility Modifications" showed a significant difference in multigroup analysis.

Initially, the two groups were analyzed separately. Then, the difference between the groups was analyzed using the PLS-MGA method. In the group of total respondents, the Physical Environmental Factors (PEF) have a path force of magnitude $0.223(\beta)$ in work engagement. We compared if the result with the group mod (where facilities have changed) shows the weight change in the physical environment (PEF). In this group, the same path had a coefficient of $0.437(\beta)$; therefore, the effect was almost twice as strong as that of the group of total respondents.

On the other hand, the parameters of the NMod group (in which the facilities did not undergo modifications) show the weight that these employees give to the new work practices (NWW) when the physical environment factors (PEF) are not yet noticed as ideal for the execution of their functions, in the employee engagement (EIN). For this group, the structural coefficient of the $\mathrm{PEF} \rightarrow \mathrm{EIN}$ ratio was only 0.093 . This index is put into perspective by comparing the same indices for the group of total respondents and the group in which the facilities were modified (respectively, $\beta=0.223$ and $\beta=0.437$ ).

Table 10 presents indexes to verify the significance of the paths. As a way of facilitating the interpretation of the results, the red indices indicate that the statistical significance of the structural coefficients $(\beta)$ in the respective paths has not been proven. The green indices demonstrate the statistical significance of the paths. 
Table 10. Analysis of model parameters by modifications in the physical environment.

\begin{tabular}{ccccccccc}
\hline Ways & $\beta$ NMod & $\beta$ Mod & $\begin{array}{c}\text { Dev } \\
\text { NMod } \\
\text { Standard }\end{array}$ & $\begin{array}{c}\text { Dev } \\
\text { Mod } \\
\text { Pattern }\end{array}$ & $\begin{array}{c}t \text { NMod } \\
\text { Values }\end{array}$ & $\begin{array}{c}t \text { Values } \\
\text { Mod }\end{array}$ & $\begin{array}{c}p \text { Values } \\
\text { NMod }\end{array}$ & $\begin{array}{c}\text { Mod } p \\
\text { Values }\end{array}$ \\
\hline $\mathrm{PEF} \rightarrow \mathrm{EIN}$ & 0.093 & 0.437 & 0.149 & 0.211 & 0.625 & 2.069 & 0.532 & 0.039 \\
$\mathrm{PEF} \rightarrow \mathrm{NWW}$ & 0.475 & 0.640 & 0.090 & 0.083 & 5.284 & 7.717 & 0.000 & 0.000 \\
$\mathrm{NWW} \rightarrow \mathrm{EIN}$ & 0.676 & 0.171 & 0.116 & 0.201 & 5.846 & 0.850 & 0.000 & 0.395 \\
\hline
\end{tabular}

Source: Research Data (2019). Note: PEF-Physical Environment Factors; NWW-New Ways of Working; EIN-Work Engagement. $\beta$-Standardized path coefficient; NMod-Group in which the facilities have not been modified; Mod-Group the facilities were modified.

Another conclusion that can be drawn from the individual analysis of the two groups is that the $\mathrm{PEF} \rightarrow \mathrm{NWW}$ path was significant in both groups. In the Mod group, the coefficient was 0.640 and in the NMod group, the coefficient was 0.475 .

By analyzing the difference in path effects between the two groups (NMod and Mod) it is possible to make additional inferences. Observing Table 11, it can be observed that of the three structural relationships of the model, the only way that showed a difference statistically significant effects on the strength among groups was on the relationship between NWW and the work engagement (EIN). In this way, the difference of effects was $0.506(\beta)$.

Table 11. Analysis of path effect differences between groups.

\begin{tabular}{ccc}
\hline Ways & $\beta$ (NMod-Mod) & $\boldsymbol{p}$ Values (NMod-Mod) \\
\hline $\mathrm{PEF} \rightarrow \mathrm{EIN}$ & 0.344 & 0.908 \\
$\mathrm{PEF} \rightarrow \mathrm{NWW}$ & 0.165 & 0.925 \\
$\mathrm{NWW} \rightarrow \mathrm{EIN}$ & 0.506 & 0.012 \\
\hline
\end{tabular}

Figure 3 summarizes the relationships prevailing in both groups.

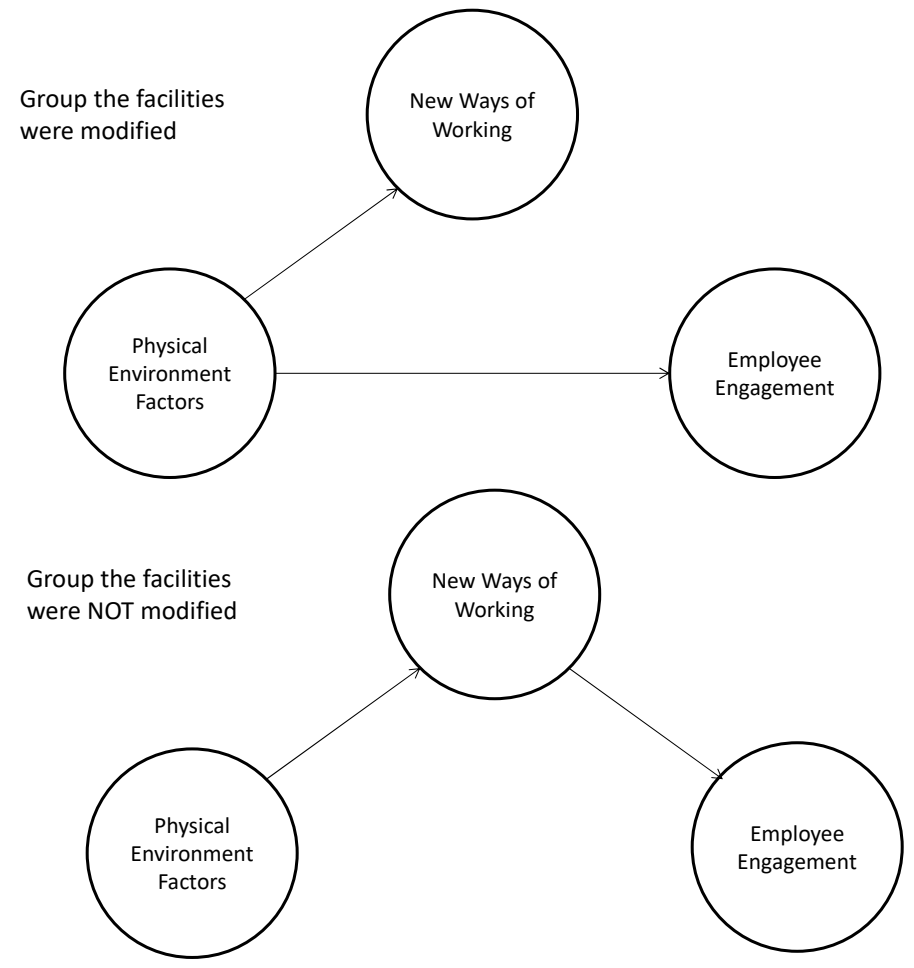

Figure 3. Group comparison summary. 


\section{Discussion and Conclusions}

The implementations of the facets of New Ways of Working involve changes in the physical environment, in IT, in management and culture organizations [8,47]. The purpose of the research was to achieve this. It has been shown empirically that changes in the physical environment directly and positively influence work engagement. However, this influence also occurs indirectly, using the adoption of practices of the facets of NWW.

By analyzing the NMod group separately, engagement is attributed to the facets of the NWW. On the other hand, in the Mod group, this relationship is reversed, work engagement is attributed to physical environment factors. When comparing the difference of the effect of the structural coefficients between the groups, there is a difference of 0.506 , a significant $95 \%(p<0.05)$ for the path NWW $\rightarrow$ EIN.

This result indicates that, for the NMod group, the facets of NWW predict with greater force the work engagement (EIN) than the group Mod. The investigation of Meulensteen et al. [70] is placed in perspective. In a work that focused on public office work facilities in the Netherlands, the authors concluded that the more employees realized that the work environment was comfortable, the greater the work engagement.

This interdependent relationship found in the results of the present study is in line with the opinions of Van Heck (2010) and corroborates the findings of Gerards et al. [3] that proper planning of both physical spaces and work forms is essential for increased work engagement and organizational performance.

The above observation aims to contextualize how the present investigation can help practice and academia. For practice, the results show that organizations that want to implement facets of New Ways of Work should assess the perception of its employees to identify the weight of the factors of the physical environment in the benefits that the NWW can provide. Moreover, when making changes to the physical workspace, they should consider how the implemented NWW practices will be influenced by such changes.

The role of New Ways of Working in employee engagement is still investigated by several scholars such as Gerards et al. [3] and Baudewijns et al. [71]. However, the investigation of the influence of physical environmental factors on this relationship still lacked studies of the research content presented in this document.

The empirical demonstration of the interrelationship between changes in the physical environment and the facets of the new ways of working (this partly mediates the relationship between NWW facets and work engagement) has the potential to extend the benefits of investments in the reformulation of physical workspaces and the management of organizations themselves.

Our results present important findings for human resource managers. First of all, they realize that it is not necessary to implement the full range of NWW to increase engagement. Betting on these facets all have very high costs, being important to select only one or two options to obtain interesting results.

Another important issue is related to management skills. The implementation of NWW requires new knowledge and skills from the managers. It will then be interesting to conduct a diagnosis that allows knowing the manager's level of knowledge and preparing the necessary training actions.

Thirdly, there is the aspect of physical working conditions that has a direct effect on engagement, which is enhanced by the mediating effect of the NWW facets. In this context, investments made in physical working conditions may bring better results if accompanied by the implementation of one of the facets of the NWW. In the current pandemic situation resulting from COVID-19, it will be interesting to implement changes in working conditions that favor distance working.

As a limitation of the research, it is possible to mention that even though the sample obtained was statistically valid to achieve the proposed research objectives, a larger number of respondents would allow for more in-depth testing of structural equation modeling analysis and proceed in one-step confirmatory research. 
As a major suggestion for future research, it is recommended to test a structural equation model in which each of the five facets of the new ways of working is positioned as a mediator of the relationship between physical environment factors and work engagement.

Future investigation of the relationship between the physical environments, the facets of new ways of working, and work engagement can shed light on how technology and human capabilities can be combined with the physical environment in which work takes place. For this next step to be taken, further research is needed.

Author Contributions: Conceptualization, L.D. and R.C.; Methodology, L.D. and R.C.; Validation, Á.D., L.P. and J.S.; Formal Analysis, L.D. and Á.D.; Investigation, X.X.; Resources, N.A.; Data Curation, Á.D.; Writing-Original Draft L.D., Á.D. and J.S. All authors have read and agreed to the published version of the manuscript.

Funding: This research received no external funding.

Conflicts of Interest: The authors declare no conflict of interest.

\section{References}

1. Delanoeije, J. New Ways of Working: An Aid for Employees? Understanding Inconsistencies in the Relationship between Work-Home Practices and Employees' Home and Work Outcomes. Ph.D. Thesis, KU Leuven, Brussels, Belgium, 2019. Available online: https://lirias.kuleuven.be/2785918?limo=0 (accessed on 10 January 2020).

2. Palvalin, M. Knowledge Work Performance Measurement in the New Ways of Working Context. Master's Thesis, Tampere University, Tampere, Finland, 2019. Available online: https:/tutcris.tut.fi/portal/files/ 18261056/palvalin_47.pdf (accessed on 10 January 2020).

3. Gerards, R.; De Grip, A.; Baudewijns, C. Do new ways of working increase work engagement? Pers. Rev. 2018, 47, 517-534. [CrossRef]

4. Hendrickx, F. Regulating new ways of working: From the new 'wow'to the new 'how'. Eur. Labour Law J. 2018, 9, 195-205. [CrossRef]

5. Jemine, G. Organizing Strategic Decision: Decisional Work in New Ways of Working Projects. Ph.D. Thesis, Université de Liège, Liège, Brussels, 2019. Available online: https://orbi.uliege.be/bitstream/2268/233316/1/ Thesis_Orbi.pdf (accessed on 25 January 2020).

6. Kingma, S. New ways of working (nww): Work space and cultural change in virtualizing organizations. Cult. Organ. 2018, 25, 1-25. [CrossRef]

7. Zienkowski, J.; Dufrasne, M.; Derinöz, S.; Patriarche, G. Les Logiques Interprétatives Managériales des Nouvelles Manières de Travailler: Ambiguités et Silences dans les Critiques des Nwow (New Ways of Working); Le côté Obscur de la Communication des Organisations: Bordeaux, France, 2019; Paper Presented at conference Org\&Co.

8. Blok, M.; Groenesteijn, L.; Schelvis, R.; Vink, P. New ways of working: Does flexibility in time and location of work change work behavior and affect business outcomes? Work 2012, 41, 2605-2610. [CrossRef]

9. Fooks, C.; Goldhar, J.; Wodchis, W.P.; Baker, G.; Coutts, J. New voices, new power, new ways of working: Bringing integrated care to the national health service in england. Healthc. Q. 2019, 21, 32-36. [CrossRef] [PubMed]

10. Fauconneau-Dufresne, S.; Jemine, G.; Pichault, F.; Rondeaux, G. Beyond Flexibility: Confronting Normative and Lived Spaces of New Ways of Working; University of Liège: Liège, Brussels, 2018; Available online: https://orbi.uliege.be/bitstream/2268/225836/1/WP\%20NWoW\%20OAP\%20v6.pdf (accessed on 25 January 2020).

11. Van Steenbergen, E.F.; Van Der Ven, C.; Peeters, M.C.W.; Taris, T.W. Transitioning towards new ways of working: Do job demands, job resources, burnout, and engagement change? Psychol. Rep. 2018, 121, 736-766. [CrossRef]

12. Canepa, E.P.B. New Ways of Working and Their Impact on Future Physical Work Spaces. Master's Thesis, Norwegian University of Science and Technology, Trondeheim, Norway, 2011. Available online: https://brage.bibsys.no/xmlui/bitstream/handle/11250/278626/2011_EVU_Masteroppgave_Erick-PaulCanepa-Beltran.pdf?sequence $=1$ (accessed on 25 January 2020).

13. Rona, J. Reel world: Finding new ways of working with and without technology. Keyboard Lazaneo Calif. 2003, 29, 122-123. 
14. Rana, S.; Ardichvili, A.; Tkachenko, O. A theoretical model of the antecedents and outcomes of employee engagement: Dubin's method. J. Workplace Learn. 2014, 26, 249-266. [CrossRef]

15. Maden, C. Linking high involvement human resource practices to employee proactivity: The role of work engagement and learning goal orientation. Pers. Rev. 2015, 44, 720-738. [CrossRef]

16. Peters, P.; Kraan, K.; van Echtelt, P. Floreren onder condities van Het Nieuwe Werken: Minder burnout, meer toewijding? Tijdschr. Arb. 2013, 3, 304-321.

17. Jupp, S. New Ways of Working (Thorogood Report); Hawksmere: London, UK, 2000.

18. De Leede, J.; Nijland, J. Understanding Teamwork Behaviors in the Use of New Ways of Working. In New Ways of Working Practices (Advanced Series in Management); Leede, J.D., Ed.; Emerald Group Publishing Limited: Bingley, UK, 2016; Volume 16, pp. 73-94.

19. De Leede, J.; Heuver, P. New Ways of Working and Leadership: An Empirical Study in the Service Industry. In New Ways of Working Practices (Advanced Series in Management); Leede, J.D., Ed.; Emerald Group Publishing Limited: Bingley, UK, 2016; Volume 16, pp. 49-71.

20. Moll, F.; De Leede, J. Fostering Innovation: The Influence of New Ways of Working on Innovative Work Behavior. In New Ways of Working Practices (Advanced Series in Management); Emerald Group Publishing Limited: Bingley, UK, 2016; Volume 16, pp. 95-143.

21. De Leede, J.; Kraijenbrink, J. The Mediating Role of Trust and Social Cohesion in the Effects of New Ways of Working: A Dutch Case Study. In Human Resource Management, Social Innovation and Technology; Bondarouk, T., Olivas-Luján, M.R., Eds.; Emerald Group Publishing Limited: Bingley, UK, 2014; Volume 14, pp. 3-20.

22. Slagter, M. Het nieuwe werken ontrafeld. Over bricks, bytes \& behavior. J. Soc. Interv. Theory Pract. 2011, 20, 118-121.

23. Christersson, M.; Heywood, C.; Rothe, P. Social impacts of a short-distance relocation process and new ways of working. J. Corp. Real Estate 2017, 19, 265-284. [CrossRef]

24. Branine, M. Part-time work and jobsharing in health care: Is the nhs a family-friendly employer? J. Health Organ. Manag. 2003, 17, 53-68. [CrossRef] [PubMed]

25. Kossek, E.E.; Lee, M.D. Implementing a reduced-workload arrangement to retain high talent: A case study. Psychol. Manag. J. 2008, 11, 49-64. [CrossRef]

26. Eskola, A. Knowledge Work and New Ways of Working. In Navigating through Changing Times: Knowledge Work in Complex Environments; Eskola, A., Ed.; Routledge: London, UK, 2017.

27. Ruostela, J.; Lönnqvist, A.; Palvalin, M.; Vuolle, M.; Patjas, M.; Raij, A.-L. ‘New ways of working'as a tool for improving the performance of a knowledge-intensive company. Knowl. Manag. Res. Pract. 2015, 13, 382-390. [CrossRef]

28. Stolwijk, C. Working Apart Together (Wat Relationship): New Ways of Working and Organizational Commitment and Job Satisfaction, and the Moderating Effects of Employee Territoriality, Task Dependency and Leadership Support. Master's Thesis, Leiden University, Leiden, NL, USA, 2015. Available online: https://openaccess.leidenuniv.nl/handle/1887/36084 (accessed on 25 January 2020).

29. Bakker, A.B.; Albrecht, S.L.; Leiter, M.P. Key questions regarding work engagement. Eur. J. Work Organ. Psychol. 2011, 20, 4-28. [CrossRef]

30. Bakker, A.B.; Leiter, M.P. Where to Go From Here: Integration and Future Research on Work Engagement. In Work Engagement: A Handbook of Essential Theory and Research; Bakker, A.B., Leiter, M.P., Eds.; Hove, Psychology Press: East Sussex, UK, 2010; pp. 181-196.

31. Demerouti, E.; Derks, D.; Ten Brummelhuis, L.; Bakker, A.B. New ways of working: Impact on working conditions, work-family balance, and well-being. In The Impact of ICT on Quality of Working Life; Korunka, C., Hoonakker, P., Eds.; Springer: Dordrecht, The Netherlands, 2014; pp. 123-141.

32. Bakker, A.B.; Demerouti, E.; Ten Brummelhuis, L.L. Work engagement, performance, and active learning: The role of conscientiousness. J. Vocat. Behav. 2012, 80, 555-564. [CrossRef]

33. Becker, F.; Sims, W. Offices that Work: Balancing Communication, Flexibility and Cost. 2001. Available online: https://docplayer.net/35949450-Offices-that-work-balancing-communication-flexibility-and-costfranklin-becker-ph-d-william-sims-ph-d.html (accessed on 25 January 2020).

34. Duffy, F.; Powell, K. The New Office; Conran Octopus: London, UK, 1997.

35. Kamarulzaman, N.; Saleh, A.A.; Hashim, S.Z.; Hashim, H.; Abdul-Ghani, A.A. An overview of the influence of physical office environments towards employee. Procedia Eng. 2011, 20, 262-268. [CrossRef] 
36. Raziq, A.; Maulabakhsh, R. Impact of working environment on job satisfaction. Procedia Econ. Financ. 2015, 23, 717-725. [CrossRef]

37. Dainoff, M.J. Ergonomic Improvements in Vdt Workstations: Health and Performance Effects Promoting Health and Productivity in the Computerized Office; Taylor \& Francis/Hemisphere: Bristol, PA, USA, 1991; pp. $49-67$.

38. Dainoff, M.J.; Cohen, B.G.F.; Dainoff, M.H. The effect of an ergonomic intervention on musculoskeletal, psychosocial and visual strain of vdt data entry work: The united states part of the international study. Int. J. Occup. Saf. Ergon. 2005, 11, 49-63. [CrossRef]

39. Kim, J.; De Dear, R. Workspace satisfaction: The privacy-communication trade-off in open-plan offices. J. Environ. Psychol. 2013, 36, 18-26. [CrossRef]

40. Kohlert, C. Wellbeing at New Ways of Working-Acoustics. In Proceedings of the INTER-NOISE and NOISE-CON Congress, Hamburg, Germany, 20-24 August 2016.

41. Gumbaketi, B. A Study of Integrated poe Technique for Assessing Workplace Constraints and Crowding. Ph.D. Thesis, University of Auckland, Auckland, New Zealand, 2000.

42. Stokols, D. On the distinction between density and crowding: Some implications for future research. Psychol. Rev. 1972, 79, 275-279. [CrossRef] [PubMed]

43. Ten Brummelhuis, L.; Bakker, A.B.; Hetland, J.; Keulemans, L. Do new ways of working foster work engagement? Psicothema 2012, 24, 113-120. [PubMed]

44. Vischer, J.; Wifi, M. The Effect of Workplace Design on Quality of Life at Work. In Handbook of Environmental Psychology and Quality of Life Research; Fleury-Bahi, G., Pol, E., Navarro, O., Eds.; Springer: Cham, Switzerland, 2017; pp. 387-400.

45. Preiser, W.F.E.; Vischer, J.C. The Evolution of Building Performance Evaluation: An Introduction. In Assessing Building Performance; Preiser, W., Vischer, J., Eds.; Routledge: London, UK, 2006; pp. 25-36.

46. Johri, P.M. Developing positive work place practices and new ways of working. Small Enterp. Dev. Manag. Ext. J. 2018, 33, 1-10.

47. Van Heck, E. New ways of working: Microsoft's 'mobility' office. RSM Discov. Manag. Knowl. 2010, 4, 4-6.

48. Seawright, J.; Gerring, J. Case selection techniques in case study research: A menu of qualitative and quantitative options. Political Res. Q. 2008, 61, 294-308. [CrossRef]

49. McGann, J.G. 2018 Global Go to Think Tank Index Report; University of Pennsylvania: Philadelphia, PA, USA, 2019.

50. Fgv. Retrieved 11 de Setembro 2019. 2019. Available online: https://portal.fgv.br/institucional (accessed on 25 January 2020).

51. Yin, R.K. Case Study Research and Applications: Design and Methods; Sage publications: Thousand Oaks, CA, USA, 2017.

52. Qualtrics Inc. The System of Actionthat Turnscustomers into Fanatics Products into Obsessions Employees into Ambassadors Brands into a Religion; Qualtrics: Provo, UT, USA, 2013; Available online: https://www.qualtrics. com/ (accessed on 25 January 2020).

53. Pedhazur, E.J.; Schmelkin, L.P. Measurement, Design, and Analysis: An Integrated Approach; Psychology Press: Hove, UK, 2013.

54. Hinkin, T.R. A brief tutorial on the development of measures for use in survey questionnaires. Organ. Res. Methods 1998, 1, 104-121. [CrossRef]

55. Koufteros, X.A. Testing a model of pull production: A paradigm for manufacturing research using structural equation modeling. J. Oper. Manag. 1999, 17, 467-488. [CrossRef]

56. Malhotra, N.K. Pesquisa de Marketing: Uma Orientação Aplicada; Bookman: Porto Alegre, Brasil, 2012.

57. Faul, F.; Erdfelder, E.; Lang, A.-G.; Buchner, A. G* power 3: A flexible statistical power analysis program for the social, behavioral, and biomedical sciences. Behav. Res. Methods 2007, 39, 175-191. [CrossRef]

58. Hair, J.F.; Hult, G.T.M.; Ringle, C.; Sarstedt, M. A Primer on Partial Least Squares Structural Equation Modeling (pls-sem), 2nd ed.; Sage Publishing: Thousand Oaks, CA, USA, 2017.

59. Matthews, L.; Hair, J.; Matthews, R. Pls-sem: The holy grail for advanced analysis. Mark. Manag. J. 2018, 28, 1-13.

60. Henseler, J.; Ringle, C.M.; Sinkovics, R.R. The Use of Partial Least Squares Path Modeling in International Marketing. In New Challenges to International Marketing; Emerald Group Publishing Limited: Bingley, UK, 2009; pp. 277-319. 
61. Bagozzi, R.P.; Yi, Y. On the evaluation of structural equation models. J. Acad. Mark. Sci. 1988, 16, 74-94. [CrossRef]

62. Hair, J.; Babin, B.; Money, A.; Samouel, P. Fundamentos de Métodos de Pesquisa em Administração; Bookman: Porto Alegre, Brasil, 2005.

63. Fornell, C.; Larcker, D.F. Structural equation models with unobservable variables and measurement error-algebra and statistics. J. Mark. Res. 1981, 18, 382-388. [CrossRef]

64. Henseler, J.; Ringle, C.M.; Sarstedt, M. A new criterion for assessing discriminant validity in variance-based structural equation modeling. J. Acad. Mark. Sci. 2015, 43, 115-135. [CrossRef]

65. Harman, H.H. Modern Factor Analysis; University of Chicago Press: Chicago, IL, USA, 1976.

66. Podsakoff, P.M.; Mackenzie, S.B.; Lee, J.-Y.; Podsakoff, N.P. Common method biases in behavioral research: A critical review of the literature and recommended remedies. J. Appl. Psychol. 2003, 88, 879. [CrossRef] [PubMed]

67. Baron, R.M.; Kenny, D.A. The moderator-mediator variable distinction in social psychological research: Conceptual, strategic, and statistical considerations. J. Personal. Soc. Psychol. 1986, 51, 1173. [CrossRef]

68. Cohen, J. Statistical Power Analysis for the Behavioral Sciences, 2nd ed.; Lawrence Erlbaum Associates: Mahwah, NJ, USA, 1988.

69. Vieira, V.A. Moderação, mediação, moderadora-mediadora e efeitos indiretos em modelagem de equações estruturais: Uma aplicação no modelo de desconfirmação de expectativas. Rev. de Adm. RAUSP 2009, 44, 17-33.

70. Meulensteen, K.; Le Blanc, P.; Kemperman, A. Influence of the Physical Work Environment on Work Engagement and Performance. In Proceedings of the 24th Annual Conference of the European Real Estate, Delft, The Netherlands, 28 June-1 July 2017.

71. Baudewijns, C.; Gerards, R.; De Grip, A. New Ways of Working and Work Engagement; GSBE Research Memoranda; Maastricht University: Maastricht, The Netherlands, 2015; Available online: https:/cris.maastrichtuniversity.nl/portal/en/publications/new-ways-of-working-andwork-engagement(846c45b8-7c5b-4c71-b71b-c48be213ff29).html (accessed on 25 January 2020).

(C) 2020 by the authors. Licensee MDPI, Basel, Switzerland. This article is an open access article distributed under the terms and conditions of the Creative Commons Attribution (CC BY) license (http://creativecommons.org/licenses/by/4.0/). 